\title{
An overview of recent progress in the implementation of the Global Strategy for Plant Conservation - a global perspective
}

\author{
Suzanne Sharrock ${ }^{1,4}$, Robert Hoft $^{2} \&$ Braulio Ferreira de Souza Dias ${ }^{3}$
}

\begin{abstract}
The Global Strategy for Plant Conservation (GSPC) with its 16 outcome-orientated targets aimed at achieving a series of measurable goals was adopted by the Conference of the Parties to the Convention on Biological Diversity (CBD) at its sixth meeting (COP-6) in 2002. In 2010, at COP-10, these targets were updated, taking into account progress at the time. To date, a number of countries have developed national responses to contribute to the GSPC, including several mega-diverse countries and other plant rich countries and regions. Additionally, a number of global initiatives have been established to promote the implementation of the GSPC. This paper provides an overview of progress at the global level towards the GSPC targets, highlighting actions that have taken place at a supra-national level, as well as providing examples of good practice in national implementation. The GSPC has been widely adopted, particularly by the botanic garden community, and while unlikely to achieve its ultimate goal of halting the loss of plant diversity by 2020, has achieved many successes, not least in allowing and facilitating many individuals and organisations from the botanical community to engage with the CBD and to contribute to the achievement of its objectives, targets and priorities.
\end{abstract}

Key words: GSPC targets overview, National Strategic Plans for Plant Conservation.

\section{Resumo}

A Estratégia Global para Conservação das Plantas (GSPC, sigla em inglês) com suas 16 metas de resultado tendo como alvo o alcance de objetivos mensuráveis foi adotada pela Conferência das Partes da Convenção sobre Diversidade Biológica (CDB) em sua sexta reunião (COP-6) em 2002 e em 2010, na COP-10, estas 16 metas de resultado foram atualizadas, tomando em conta o progresso realizado até então. Ao fazê-lo foi decidido que a implementação da GSPC deveria ser promovida como parte da moldura maior do Plano Estratégico para Biodiversidade 2011-2020. Até a presente data, vários países desenvolveram respostas nacionais para contribuir para a GSPC, incluindo vários países mega-diversos e outros países e regiões ricos em plantas. Adicionalmente, várias iniciativas internacionais foram estabelecidas para promover a implementação da GSPC. Este artigo oferece um panorama do progresso a nível global para o alcance das metas da GSPC, destacando ações tomadas no nível supra-nacional bem como boas práticas de implementação a nível nacional. A informação apresentada utilizou dados dos relatórios de progresso elaborados em 2013, 2014 e 2016, baseados em grande parte nas informações submetidas por membros da Parceria Global para Conservação das Plantas (GPPC, sigla em inglês), bem como dados da literatura recente.

Palavras-chave: Panorama das metas globais da GSPC, Planos Estratégicos Nacionais para a Conservação das Plantas.

\section{Introduction}

The Global Strategy for Plant Conservation (GSPC) with its 16 outcome-orientated targets aimed at achieving a series of measurable goals by 2010 , was adopted by the Conference of the
Parties to the Convention on Biological Diversity at its sixth meeting (COP-6) in 2002.

The Strategy was updated in 2010 and a set of revised targets for 2020 were adopted at COP-10 in 2010. The development of the GSPC is described

\footnotetext{
Botanic Gardens Conservation International - BGCI, Descanso House, 199 Kew Road, Richmond, Surrey, TW9 3BW, UK.

${ }^{2}$ Secretariat of the Convention on Biological Diversity, 413, Saint Jacques Street, suite 800, Montreal QC H2Y 1N9, Canada.

${ }^{3}$ University of Brasilia, Ecology Department, Campus Darcy Ribeiro, 70910-900, Brasília, DF, Brazil.

${ }^{4}$ Author for correspondence: Suzanne.Sharrock@bgci.org
} 
by Lovett (2004) and the major steps outlined in Table 1.

To date, a number of countries have developed national responses to the GSPC, including several mega-diverse countries (e.g., Brazil, China, Colombia, Mexico, Philippines and South Africa) and other plant rich countries and regions (e.g., Australia, North America, Europe and Spain). Other countries are implementing the GSPC - explicitly or implicitly - through their National Biodiversity Strategies and Action Plans (NBSAPs). Joppa et al. (2013) analysed plant conservation needs and their implications for planning protected areas in the context of Aichi Biodiversity Target 11 and concluded that major plant conservation objectives could be achieved if protected areas were systematically located in areas of high biodiversity value.

\section{Methods}

This review builds on earlier assessments of progress in the implementation of the GSPC and challenges for its implementation, such as that undertaken at the national level in Brazil in 2013 (Dias \& Hoft 2013).

Globally, a mid-term review of progress was undertaken in 2014, combining data from national plant conservation strategies, $5^{\text {th }}$ National CBD reports, National Biodiversity Strategies and Action Plans, submissions from members of the Global Partnership for Plant Conservation and information published on the GSPC Toolkit $(<\mathrm{http} / / / \mathrm{www}$. plants2020.net $>$ ). This review was published as a companion to the fourth edition of the Global Biodiversity Outlook (Sharrock et al. 2014) and concluded that progress was being made towards the achievement of most of the sixteen targets of the GSPC but that in most cases it was not sufficient to achieve the targets by 2020 .

Further data on progress towards the targets was collected in 2016 for the first meeting of the Convention's Subsidiary Body on Implementation (CBD 2016a).

This paper draws largely on these progress reports prepared in 2014 and 2016, and provides an overview of progress at the global level towards the GSPC targets, highlighting actions that have taken place at a supra-national level, as well as providing examples of national implementation. (Figs. 1a-d; 2a-d).

\section{Results}

Progress towards the GSPC targets

Progress towards the targets of the GSPC is variable both between targets and between countries. As countries are encouraged to implement the GSPC within the broader framework of the CBD's Strategic Plan, implementation is largely at the national level. However, as the GSPC targets are set at the global level this has, in some cases, promoted global responses and a number of new initiatives and consortia have been formed around specific targets (Figs. 3a-d; 4a-d). These are highlighted in this section, together with examples of national implementation on a target by target basis.

Target 1: an online flora of all known plants

A widely accessible Flora of all known plant species, (present estimates indicate that there are at least 390,000 species of vascular plants (RBG

Table 1 - An overview of the development of the GSPC.

\begin{tabular}{ll}
\hline Date & Activity \\
\hline 1999 & Establishment of the Gran Canaria Group and its Gran Canaria Declaration \\
2000 & Decision at CBD COP-5 to consider establishment of a Global Strategy for Plant Conservation at COP-6 \\
2002 & $\begin{array}{l}\text { Adoption of the GSPC at COP-6 marking the first adoption of targets for biodiversity conservation by the } \\
\text { international community. }\end{array}$ \\
& $\begin{array}{l}\text { Establishment of the Global Partnership for Plant Conservation (GPPC) at COP-7 to support national } \\
\text { implementation of the GSPC. The GPPC now includes over 50 institutions, organizations and networks } \\
\text { with national, regional and international programmes in plant conservation. }\end{array}$ \\
& $\begin{array}{l}\text { GSPC targets updated for 2020, taking into account progress that had been made (SCBD, 2009) and } \\
\text { adopted at COP-10, with a decision that implementation of the GSPC should be pursued as part of the } \\
\text { broader framework of the Strategic Plan for Biodiversity 2011-2020. }\end{array}$ \\
&
\end{tabular}



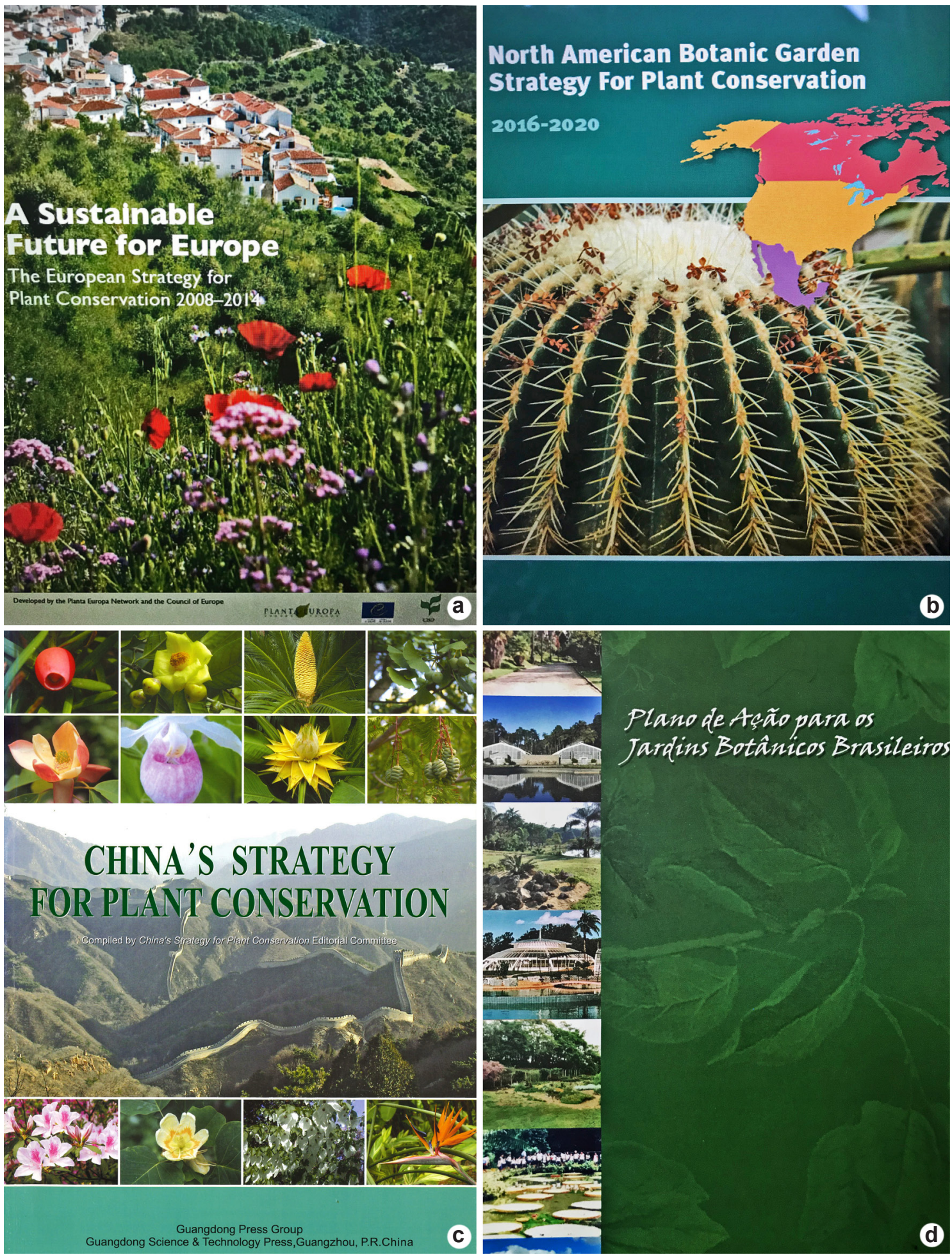

Figure 1 - Covers of selected regional and national plant conservation strategies in support of the GSPC: a. A sustainable future for Europe, the european strategy for plant conservation (2008-2014), Plant Europa, 2008; b. North American Botanic Garden strategy for plant conservation (2016-2020), Botanic Gardens Conservation International, US, 2016; c. China's strategy for plant conservation, China's strategy for plant conservation editorial committee, 2008 ; d. Action plan for the Brazilian botanic gardens (2004-2014). 

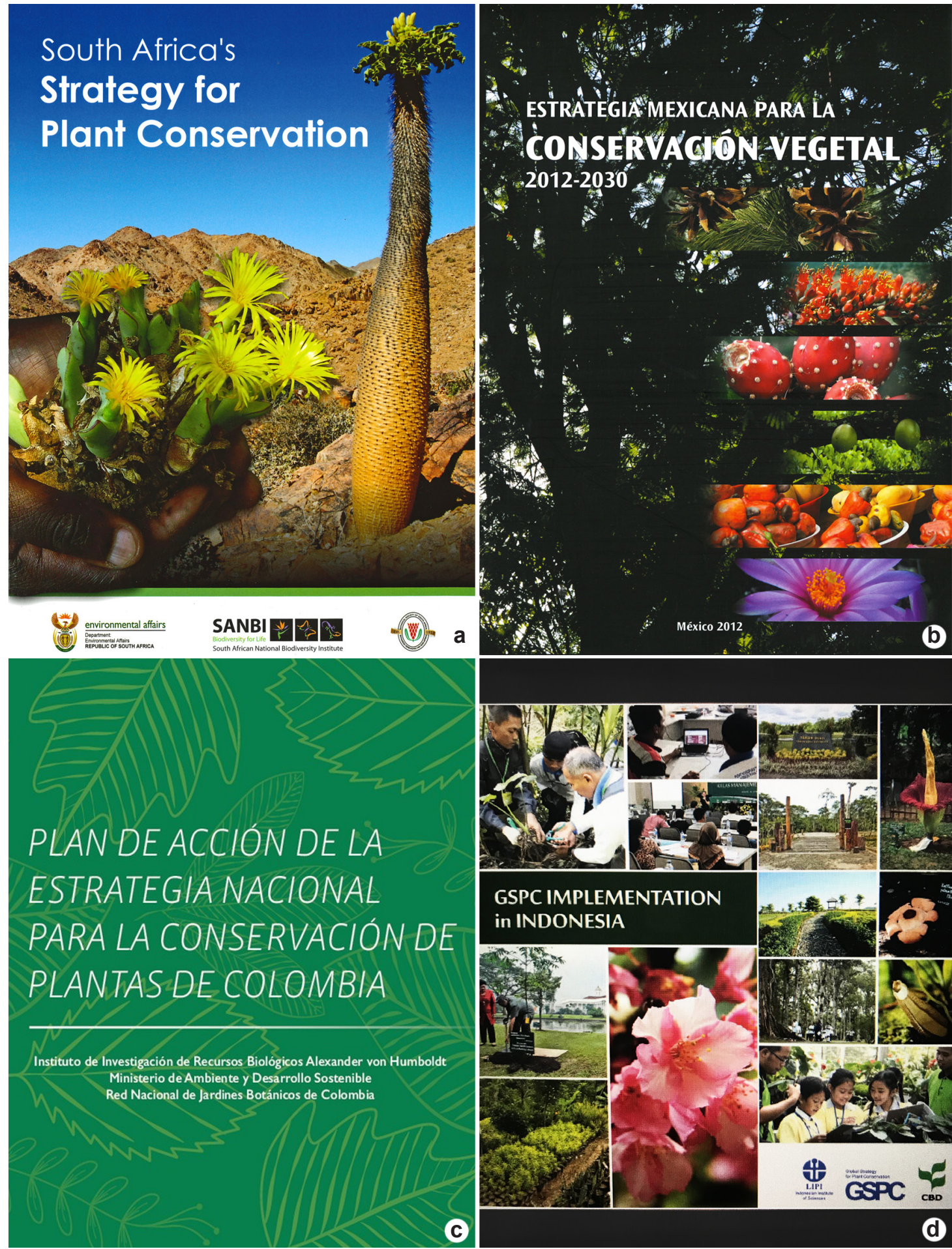

Figure 2 - Additional covers of national plant conservation strategies in support of the GSPC: a. South Africa's strategy for plant conservation (2016-2020), South Africa National Biodiversity Institute (SANBI) \& Botanical Society of South Africa, 2015; b. Mexican strategy for plant conservation (2012-2030), Comisión Nacional para el Conocimiento y Uso de la Biodiversidad (CONABIO), 2012; c. Action plan for Colombian plant conservation (2018-2030), Instituto de Investigación de Recursos Biológicos Alexandre von Humboldt \& Rede Nacional de Jardines Botánicos de Colombia, 2017; d. GSPC Implementation in Indonesia, Bogor Botanic Garden/Indonesian Institute of Sciences (LIPI), 2014. 
Kew 2016) and 20,000 species of bryophytes (The PlantList 2013) is a fundamental requirement for plant conservation and provides a baseline for the achievement and monitoring of other targets of the Strategy. The previous (GSPC 2010) Target 1 aimed to develop "a widely accessible working list of known plant species as a step towards a complete world flora," and this target was achieved at the end of 2010, as The Plant List (<http://www. theplantlist.org $>$ ). Drawing from the knowledge gained in producing The Plant List, a project to create an online world Flora of all known plant species was initiated by Missouri Botanical Garden in 2012. A World Flora Online (WFO) Council has since been formed with 41 participating institutions world-wide ${ }^{1}$.
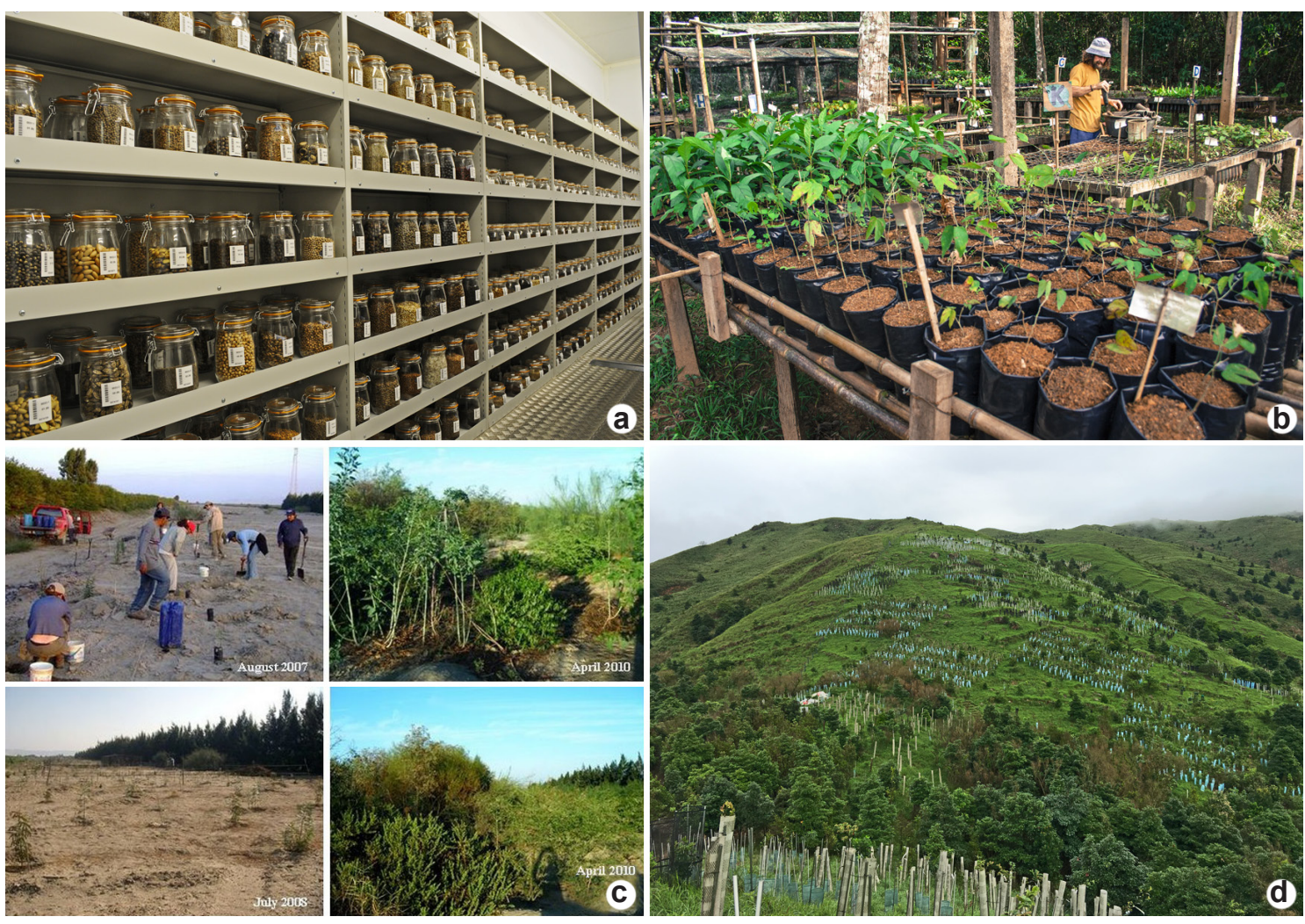

Figure 3 - Examples of kinds of activities conducted by partners under the GSPC: a. the cold room at the Germplasm Bank of Wild Species (GBOWS) at Kunming Institute of Botany, Chinese Academy of Sciences (GBOWS); b. nursery with seedlings for reforestation of the Atlantic Rainforest in Rosario do Limeira, Brazil (Alf Ribeiro/Shutterstock); c. restoration of the Huaruango woodlands in Peru by the Royal Botanic Gardens, Kew (O. Whaley); d. core area of restoration site on the upper slopes of the Kadoorie Farm and Botanic Garden premises in Hong Kong. (G. Fischer).

\footnotetext{
'Allen Herbarium, Landcare Research, New Zealand; Australian Biological Resources Study, Australia; Botanic Garden Meise, Belgium; Botanic Garden and Botanical Museum Berlin-Dahlem, Germany; Botanical Research Institute of Texas, USA; Conservatoire et Jardin Botaniques, Geneva, Switzerland; Core Facility Botanical Garden of the University of Vienna, Austria; Euro+Med Plantbase, Berlin, Germany; Flora Iberica Project, Madrid, Spain; Flora Malesiana Foundation, Leiden, Netherlands; Flora of North America Association, US \& Canada; Forest Research Institute, Malaysia; Global Biodiversity Information Facility, Denmark; Institute of Botany, Academy of Sciences of the Czech Republic; Institute of Botany, Azerbaijan National Academy of Sciences, Azerbaijan; Institute of Botany, Chinese Academy of Sciences, Beijing, China; Institute of Botany, Slovak Academy of Sciences, Slovakia; Instituto de Botánica Darwinion, Buenos Aires, Argentina; Instituto de Ecología A.C. ;Veracruz, Mexico; Instituto de Pesquisas Jardim Botânico do Rio de Janeiro, Brazil; Instituto Nacional de Ciência e Tecnologia (INCT) Virtual Herbarium ;Recife, Brazil; Komarov Institute of Botany, Russian Academy of Sciences, St. Petersburg, Russia; Korea National Arboretum, Pocheon, South Korea; Kunming Institute of Botany, Chinese Academy of Sciences, Kunming, China; Missouri Botanical Garden, St. Louis, USA; Muséum National d'Histoire Naturelle, Paris, France; National Biodiversity Institute (INBio) of Costa Rica; Santo Domingo de Heredia, Costa Rica; National Botanical Research Institute, National Herbarium of Namibia, Namibia; Natural History Museum, London, UK; Naturalis Biodiversity Center, Leiden, Netherlands; Royal Botanic Garden Edinburgh, UK; Royal Botanic Gardens Kew, UK; Smithsonian National Museum of Natural History, Washington DC, USA; South African National Biodiversity Institute, Pretoria, South Africa; Species2000/Catalogue of Life, Leiden, Netherlands; The New York Botanical Garden, NY, USA; the Nezahat Gökyigit Botanic Garden, Istanbul, Turkey; Botany Department of Trinity College Dublin, Ireland; Tsittsin Main Botanical Garden, Moscow, Russia; UNESCO Chair in Plant Conservation and Biodiversity in Macaronesia and in Western Africa, Gran Canaria, Spain; Universidad Nacional de Colombia, Bogota, Colombia.
} 
The WFO is being developed as an openaccess, web-based compendium of the world's plant species. It is a collaborative, international project, building upon existing knowledge and published floras, checklists and revisions but also requiring the collection and generation of new information on poorly known plant groups and plants in unexplored regions. The WFO utilizes a taxonomic backbone of all vascular plants and bryophytes from orders to subspecies and represents a major step forward in developing a consolidated global information service on the world's flora. Rapid progress is being made toward incorporation of descriptive data, distributions and images (Miller \& Ulate 2017). The WFO portal is available online at $<$ http:// www.worldfloraonline.org $>$.

Progress that has been made to date indicates that Target 1 will be achieved by 2020 .
Target 2: an assessment of the conservation status of all known plant species, as far as possible, to guide conservation action.

According to RBG Kew's 2016 report on the State of the World's Plants (RBG Kew 2016), one in five plant species is estimated to be threatened with extinction. The IUCN Red List of Threatened Species $^{\mathrm{TM}}$ is recognized as the most comprehensive objective global approach for evaluating the extinction risk of species and is the scientific basis underpinning many of the indicators adopted by the CBD for monitoring progress towards the achievement of the GSPC and Aichi Targets.

One critical gap however is that, to date, only a limited number of IUCN Red List assessments are available on the conservation status of plants. The IUCN Red List presently includes assessments for 23,074 plant species, of which 12,253 (53\%)
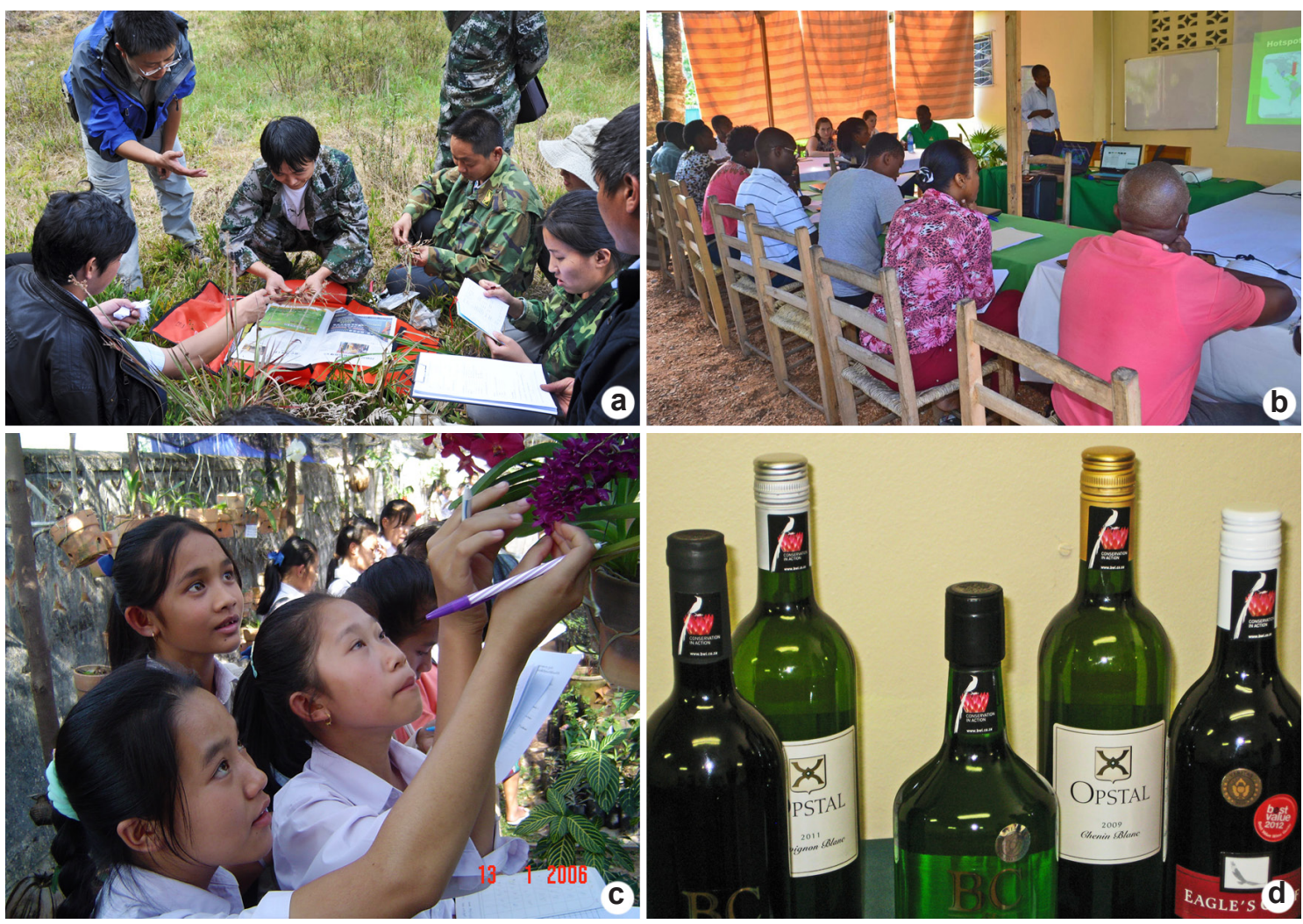

Figure 4 - Additional examples of kinds of activities conducted by partners under the GSPC. a. training in seed collecting in China (GBOWS); b. red listing training course in Haiti (M. Rivers); c. Chinese school children examining orchids in a botanic garden nursery (Bian Tan); d. wine sold under the 'Biodiversity and Wine Initiative' in South Africa. (S. Sharrock). 
Box 1 - Achieving Target 1 at the national level: the cases of Brazil, China and Colombia

Brazil: Recent progress on the implementation of the Online Brazilian Flora 2020 deserves a mention here with over a third of vascular plants now with descriptions added online and over a million exsicata of Brazilian plants with high resolution images also added online.

China: The Flora of China (FOC) is available on-line at: $<$ http://www.efloras.org/flora_page.aspx?flora_id=2>. The online functionality was greatly enhanced in 2014, with the addition of an Advanced Search function. Over 64,000 synonyms, misapplied names, Chinese names, and pinyin names, and data on elevations, Chinese provinces, and foreign countries are now searchable. Users can generate various databases for their own purposes based on FOC data, e.g., list of species of vascular plants occurring in both China and India, or China and Greece, etc. Since 2014 a full version of the Chinese translation of FOC has been available. This has greatly expanded the readership of FOC in China.

Colombia: On April 15 th 2015 , Universidad Nacional de Colombia and its partners launched the most comprehensive checklist ever documented of the plants that occur in the country. The Catalogue of the Plants and Lichens of Colombia includes contributions from 180 botanists working in 20 countries over the last 13 years. For the first time, information about the 1,674 species of lichens and 26,126 plant species that have so far been documented in the country are compiled in one on-line resource. Colombia is one of the countries with the greatest botanical diversity on the planet and this inventory is fundamental to the management and conservation of Colombia's rich natural history, Bernal et al. 2015) $<$ http://catalogoplantasdecolombia.unal.edu.co $>$

are considered to be threatened with extinction or extinct (IUCN 2017). This represents only around $6.5 \%$ of known plant species. The sample of plants for which conservation assessments are available is not only small, but also skewed, notably because assessors tend to select species that are likely to be at risk of extinction. A solution to a potential bias towards species at high risk taken by RBG Kew, was to select a suitably large, random selection of plant species and assess their extinction risk. This representative view has revealed that one in five plant species are estimated to be in the top three 'threatened' categories of Critically Endangered, Endangered or Vulnerable. Further assessments of the sample in future years will establish an overall trend in the extinction risk index for plants.

The lack of conservation assessments for plants means that monitoring global progress towards Targets 7 and 8 of the GSPC is particularly challenging. In recognition that the rate of uptake of plant assessments has been slower than that for some other taxonomic groups, the IUCN Species Survival Commission (IUCN SSC) has since 2010, made efforts to accelerate the rate of assessments for plants and publish these on The IUCN Red List. IUCN's target (based on the IUCN SSC Barometer of Life analysis) is to have 38,500 plants assessed and published online on the IUCN Red List by 2020 (Stewart et al. 2010).

To further address the gap in global conservation assessments for plants, Botanic Gardens Conservation International (BGCI), together with partners from the National Red List and the Royal Botanic Gardens, Kew, have assembled all currently available digital conservation assessments, including data from IUCN, into a single list of conservation assessments for plants. This list was launched in 2017 and is available on-line as the ThreatSearch database (<http:// www.bgci.org/threat_search.php $>$ ). It presently includes over 242,000 assessments representing over 150,000 taxa ${ }^{2}$ and is the most comprehensive database of conservation assessments for plants. ThreatSearch lists global, regional and national red list assessments for plants derived from a variety of sources and systems and the results to date show that 37,500 of the species that have been assessed are threatened at some level.

Based on an analysis of ThreatSearch data, Bachman et al. (2018) have concluded that between $33.1 \%$ and $39.7 \%$ of threatened plant species have already been identified in digitally available red lists. If attention is given to making digitally available those assessments of conservation status currently only available in paper form (mostly books); if the Global Tree Assessment is successful in its target of assessing all 60,000 tree species by 2020; and if IUCN fulfils its pledge to conclude the assessment of additional 15,500 plant species, hopefully

\footnotetext{
${ }^{2}$ The taxa included in ThreatSearch include 111,824 accepted species (according to The Plant List) as well as taxa with non-resolved names. This represents $32 \%$ of known plant species.
} 
prioritizing under assessed families and regions, we can expect to identify by 2020 at least $50 \%$ of the expected globally threatened plant species.

Good progress with Red List conservation assessments is being made at the national level, in some cases using nationally developed instruments for assessing extinction risk. (For example, Mexico developed a national method to assess species extinction risk - see Método de Evaluación del Riesgo de Extinción de las Especies Silvestres en México, MER). A unique South-South partnership involving South Africa, Brazil and Colombia has been established to share experiences and accelerate progress in Red List assessments in mega-diverse countries using the IUCN Red List Categories and Criteria. This has resulted in the publication of the Brazilian Red data book (<http://cncflora.jbrj.gov. br/arquivos/arquivos/pdfs/LivroVermelho.pdf $>$ ) - a significant contribution to the achievement of Target 2. South Africa and China, two mega-diverse countries, have already assessed the conservation status of all their floras, a huge accomplishment.

\section{Box 2 - Global Tree Assessment}

The Global Tree Assessment is an initiative led by BGCI and the IUCN/SSC Global Tree Specialist Group. It aims to provide conservation assessments of all the world's tree species by 2020. The goal of the Global Tree Assessment is to provide prioritization information to ensure that conservation efforts are directed at the right species so that no tree species becomes extinct.

Of the world's 60,065 tree species, about one-third of species have so far been evaluated for their conservation status.

Work is ongoing to develop an even more extensive global collaborative partnership, involving the coordinated effort of many institutions and individuals. These steps will enable the Global Tree Assessment to achieve its 2020 target.

$<$ http://www.bgci.org/plant-conservation/ globaltreeassessment/>

Rivers 2017.

Target 3: Information, research and associated outputs and methods necessary to implement the Strategy developed and shared

Plant conservation research, methodologies and practical techniques are fundamental to the conservation of plant diversity. While many methodologies have been developed and much relevant information generated over the past few decades, much of this lies in unpublished reports and manuscripts, not easily accessible to plant conservation practitioners.

In response to a request from the Parties to the $\mathrm{CBD}$, an on-line toolkit has been developed by BGCI and is available in all $6 \mathrm{UN}$ languages. This provides a platform for sharing information, methodologies and experiences developed by GPPC members. A wide range of tools and resources are directly accessible or linked to via the toolkit (<http://www.plants2020.net $>$ ).

A range of other tools and resources and case studies are being developed by plant conservation practitioners around the world but greater efforts are still needed to make these available in appropriate formats where they are needed.

Box 3 - A toolkit for crop wild relative conservation planning

An interactive toolkit, has been developed by Bioversity International and the University of Birmingham, UK, to guide national programmes on planning the conservation of crop wild relatives. The toolkit covers all the steps involved in conservation planning for crop wild relatives, and facilitates systematic thinking on the processes required for countries, organizations and projects to develop a strategy. The toolkit contains 13 modules, each corresponding to a different step in the conservation planning process. Every module consists of an introduction, methodology inclusive of an interactive flowchart, case studies demonstrating researchers' experiences, references, and additional helpful resources. The toolkit can be accessed at: $<$ http:// www.cropwildrelatives.org/conservation-toolkit/>

Target 4: At least 15 per cent of each ecological region or vegetation type secured through effective management and/or restoration

This target focuses on conservation of plant species through the conservation and/ or restoration of the landscapes, or ecological regions, in which they exist. This target is achieved mainly by actions taken to implement Aichi Biodiversity Targets 11 and 15. As of April 2016, of the 821 non-Antarctic terrestrial ecoregions, 378 (46\%) had reached $15 \%$ coverage, while $52(6.3 \%)$ had less than $1 \%$ coverage by protected areas (UNEP-WCMC and IUCN 2016). ${ }^{3}$ 
For Brazil, there are 32 terrestrial ecoregions with more than $80 \%$ of their area within the country, out of which 21 have at least $15 \%$ coverage by protected areas.

While it is challenging for botanists and plant conservationists to implement the GSPC's ecosystem targets, especially Targets 4 and 6 , there are areas, particularly related to ecological restoration, where botanical and horticultural expertise is especially relevant. The establishment of the Ecological Restoration Alliance of Botanic Gardens has brought together a number of partners to share experiences and raise awareness of the role of botanic gardens in supporting ecological restoration. The Alliance focuses on the use of native species in restoration and draws on the horticultural and propagation skills of botanic gardens. Members of the Alliance have agreed to support efforts to scale up the restoration of damaged, degraded and destroyed ecosystems around the world, with the goal of restoring 100 places by 2020 .

A key element in effective restoration is the availability of high quality, genetically appropriate seeds and seedlings of native species. A number of botanic gardens and other agencies have recognised this demand and are responding through the development of seed multiplication programmes. An example is the Australian National Botanic Gardens, which has embarked on a pioneering project in partnership with Greening Australia and the Centre for Australian National Biodiversity Research. The project aims to establish Seed Production Areas (SPAs) to provide seed for restoration of threatened grassy woodland and temperate grassland communities. This partnership pools specialist Australian plant knowledge, traditional ecological knowledge, horticultural expertise and best available science, together with practical biodiversity conservation and key environmental custodians, land managers and the public.

Partners of the GPPC are also contributing scientifically to support recent large-scale ecosystem restoration efforts including the African

\footnotetext{
${ }^{3}$ Details from: European Commission Joint Research Centre (JRC) and UNEP-WCMC (2016). Global analyses of protected area coverage of marine and terrestrial ecoregions. Available online at $<$ https://protectedplanet.net $/ \mathrm{c} /$ protected-planet-report-2016/protected-planet-report-2016--data--mapsfigures $>$. Access on 9 November 2017.
}

Box 4a-RBG Kew and the Great Green Wall crossborder pilot project (Burkina Faso, Mali and Niger)

Kew's Great Green Wall cross-border pilot project aims to gather environmental and social data on land restoration to help inform larger restoration projects in the Sahara and Sahel region. As part of a larger initiative to transform $8,000 \mathrm{~km}$ of desert land across Africa (<http://www.greatgreenwall.org/>), Kew is coordinating a cross border pilot project across Burkina Faso, Mali and Niger. The project aims to build a model for the restoration of large-scale agrosylvopastoral systems throughout the Sahel region. The approach taken combines the reintroduction of native trees and shrubs in a restoration framework which includes the economic and ecological rehabilitation of traditional agroforestry systems. Amongst other outputs, the project, in consultation with local communities, has developed a list of 193 useful species. Of these 55 woody and herbaceous species have been selected and propagated at community level, with over 1 million seedlings being propagated across the three countries.

$<$ https://www.kew.org/science/projects/great-greenwall-cross-border-pilot-project-burkina-faso-maliand-niger>.

Forest Landscape Restoration Initiative (AFR100) Initiative and the Great Green Wall across the African Sahel see below.

The AFR100 is a country-led effort to bring 100 million hectares of land in Africa into restoration by 2030 . Currently $80 \%$ of the overall goal has been formally commited by 24 African countries (<http://www.afr100.org/>).

Despite the fact that many African countries have made large commitments to AFR100, there is currently limited indigenous seed available in national tree seed centres, limited indigenous seedlings available in nurseries and limited knowledge on how to propagate indigenous species. Members of the Ecological Restoration Alliance botanic gardens (ERA) in East Africa are setting up forest restoration demonstration sites that test indigenous species performance and show that restoration results can be achieved quickly with indigenous species. They are also developing propagation protocols for indigenous species to make it easier for government, NGOs and other AFR100 implementing partners to incorporate a wider number of indigenous tree species in restoration projects. 
Box 4b -Forest restoration in the East African Uplands

Brackenhurst Botanic Garden's restoration of upland forest near Nairobi has become a model for East African habitat restoration initiatives. The forest in the region was once so extensive that it hosted leopard, buffalo and elephant, and blocked city residents' view of Mount Kilimanjaro. Less than $2 \%$ of original forest remained before work began, with the rest mostly transformed into tea and eucalyptus plantations. One hundred acres (40 hectares) of tropical rainforest have now been replanted. In just 12 years, the project has replaced exotic tree plantations with a 30-foot tall native forest that shelters lianas, orchids and a species-rich understory. The forest incorporates more than 500 woody plants from East Africa and is now home to over 170 species of birds, 120 species of butterfly, as well as fruit bats. The project also provides livelihoods in an area of high unemployment, by training and employing local people. Plans are underway to further expand the restored area.

Brackenhust has become a training centre for NGOs, botanic gardens and other organisations from across East Africa involved in forest restoration and has collaborated with Tooro Botanic Garden in Uganda, in the restoration of two Local Forest Reserves and one Central Forest Reserve in the Fort Portal District.

Target 5: At least $75 \%$ of the most important areas for plant diversity of each ecological region protected, with effective management in place for conserving plants and their genetic diversity

An important plant area (IPA) can be defined as a site exhibiting exceptional botanical richness and/or supporting an outstanding assemblage of rare, threatened and/or endemic plant species and/ or vegetation of high botanical value.

Plantlife International has been instrumental in developing Guidelines to support the identification of IPAs and maintains an on-line database of IPA sites and projects $(<\mathrm{https}$ // www.plantlife.org.uk/international/importantplant-areas-international $>$ ). In partnership with the Royal Botanic Gardens, Kew (RBG
Kew), a Tropical Important Plant Areas (TIPAs) programme was also launched in 2015 and revised criteria to identify IPAs were published in 2017. (Darbyshire et al. 2017). The criteria are based around a sound, scientific, global framework which acknowledges the practical problems of gathering plant and habitat data in many regions of the world, and recognises the role of peer reviewed expert opinion in the selection process. They can be applied to the conservation of all organism groups within the plant and fungal kingdoms and can work alongside the newly published Key Biodiversity Areas Standard published by IUCN (IUCN 2016).

RBG Kew has a target of carrying out IPA assessments with national partners in 7 Tropical Regions between 2015 and 2020 (Cameroon, Guinea, Mozambique, Uganda, Bolivia, the UK Overseas Territories in the Caribbean, West Papua).

Box 5 - Plant micro-reserves in Bulgaria

In Bulgaria, the National Ecological Network consists of protected areas and Natura 2000 sites. Recent developments have seen a small increase in protected area coverage and at the same time a sizable increase in numbers of protected sites. This is the result of a growing network of small protected areas for plant species in Bulgaria using the plant microreserve model. The micro-reserves were established to protect 47 rare and endangered plants located in 61 localities, which prior to this initiative were outside existing protected areas, and therefore exposed to a significant risk of extinction. Plant micro-reserves are small-sized areas (less than $20 \mathrm{ha}$ ) for protection and long-term monitoring of populations of endemic, rare and endangered plant species and vegetation types. Usually they are located on agricultural land or in forests, subject to commercial use, and they are under high anthropogenic pressure. Due to their small size, these sites require maintenance and restoration actions. For their legal protection, the sites are declared as 'protected sites' under the Bulgarian Protected Areas Act. In the process of creating this network of small protected areas, partnerships have been developed between scientists, public administrations, local authorities and communities, who join their efforts to conserve these rare plants. 
Target 6: At least $75 \%$ of production land in each sector managed sustainably, consistent with the conservation

of plant diversity

Land in production covers a substantial proportion (around one third) of the earth's land surface. Increasingly, sustainable production methods are being applied in agriculture, including organic production, integrated pest management, conservation agriculture and onfarm management of plant genetic resources. Similarly, sustainable forest management practices are being more broadly applied. However, there are questions concerning the extent to which plant conservation specifications are incorporated into such schemes. The implementation of this target is closely linked to the implementation of Aichi Biodiversity Target 7 and the work of the UN's Food and Agriculture Organisation (FAO). At the 2016 Conference of the Parties to the CBD, a platform on biodiversity and agricultural sectors was launched by FAO for governments, communities of practice and other stakeholders to build bridges between sectors, identify synergies, align goals and develop integrated cross-sectoral approaches to mainstreaming biodiversity in the agriculture, forestry and fisheries sectors" (CBD 2016c).

Box 6 - Working with the productive sector in South Africa and Brazil

Working with the production sector through mainstreaming projects is a major focus of biodiversity conservation work in South Africa. Agriculture, specifically crop cultivation, is the most severe threat to plant diversity in South Africa threatening over 1,400 plant species. Much work has been done since 2004 to work within the agricultural sector with Biodiversity and Business Initiatives (BBIs) set up for wine, potatoes, rooibos tea, sugar, indigenous cut flowers and fruit producers. Overgrazing by livestock also poses a significant threat to plant diversity and a number of non-governmental organisations (NGOs) and biome-based mainstreaming projects have worked on initiatives with the red meat industry.

All of these agriculture-based initiatives involve developing and implementing best-practice farming guidelines to minimise the impact of faming on biodiversity, as well as providing training on a range of land management techniques. Within several of these initiatives, and driven by the broader conservation sector, incentives are provided to farm owners of high biodiversity land to formally conserve land via biodiversity stewardship programmes.

$<$ http://biodiversityadvisor.sanbi.org/planning-and-assessment/plant-conservation-strategy/target-6/>.

Environmental Requirements of the Brazilian Forest Code as revised in 2012

The Brazilian Forest Code, as revised in 2012 (Law 12,651 on Protection of the Native Vegetation) building on its earlier revision of 1965 requires preservation or restoration of native vegetation in all rural estates along rivers, lakes, catchment areas, high slopes and mountain tops and the set aside of an additional percentage of each rural estate to be kept as native vegetation but where sustainable use is allowed (the minimum percentage is $20 \%$ in South, Eastern, Northeastern and South-Central Brazil, 35\% in savannas areas in North-Central Brazil and transition to the Amazon and 80\% in the Amazon region. All land owners and users have been required to upload in the online Rural Environmental Registry ( $<\mathrm{http}$ ://www.car.gov.br/\#/>) the geo-referenced information on compliance to these environmental requirements and to agree with state level or federal environmental or forest agencies on needed environmental restoration projects to comply with the law in cases where these environmental requirements are not currently met or to compensate such deficit by purchasing the equivalent amount of land covered by natural vegetation in the same biome. Land owners or renters not in compliance with these environmental requirements are denied, by the law, access to funding from public banks which are the main financers of rural development in Brazil. Currently, up to September 30 2017, the georeferenced compliance information have been uploaded by land owners for more than 3,5 million rural states/properties, which represents about 2/3 of the total number of Brazilian farms - see $<$ http://www.florestal.gov.br/modulo-de-relatorios $>$. 
Target 7: At least 75 per cent of known threatened plant species conserved in situ

In situ conservation is generally considered to be the primary approach for conservation as it ensures that species are maintained in their natural environments, allowing evolutionary processes to continue. Moreover, for some species, which are dependent on complex relationships with other species for their survival (specialised pollinators, soil bacteria etc.), it may be the only feasible conservation method. In situ conservation is also important for those plants which have recalcitrant seeds (seeds which cannot be dried and stored at low temperatures) - such as many species from the humid tropics - and for which ex situ conservation is expensive and difficult (Teixido et al. 2016).

The exact number of globally threatened plants in the world remains to be determined through the achievement of Target 2. At this stage therefore, global progress towards this target remains difficult to measure. However, much more information is available at the national level. The approach taken by South Africa provides an interesting case study of how a mega-diverse country can address this target and expect to achieve it by 2020 (see Box 7).

Despite encouraging progress in some countries, overall the continuing loss of natural habitat means that the in situ conservation status of many species is getting worse. Furthermore, many species that occur within protected areas are not effectively conserved and are affected by factors such as invasive species, climate change and unregulated harvesting.

Gutiérrez (2017) and Pyšek et al. (2017) have recently reviewed the evidence for impacts of alien invasives on the habitat quality and on the displacement and local extinction of native and endemic species, including plants, providing selected cases; whereas Harper \& Bunbury (2015) have provided a recent review on the impacts of invasive rats on the native species of tropical islands, including on plants. Auld et al. (2010) documented the disruption of recruitment of two endemic palms on Lord Howe Island due to invasive rats and Athens (2009) and Hunt \& Lipo (2012) speculated on the role of invasive rats on the collapse of lowland forests in Hawaii and Easter Islands. Importantly, Dawson et al. (2017) have provided a global overview of spatial distribution of established alien invasives and places where native species are at most risk.
Box 7 - Implementing Target 7 in South Africa

In 2014 South African botanists conducted an analysis to show that of the 2,576 threatened plants species, 1,554 $(66 \%)$ had at least one population occurring within a formally protected area. A systematic biodiversity conservation plan was conducted to identify the best sites for capturing a further $9 \%$ of threatened species needed to achieve Target 7. Only 30 additional sites need to be conserved. Following this analysis, priority sites have been included into protected area expansion programmes. 12 of the 30 sites $(40 \%)$ are under active negotiation for formal protection

Target 8: At least 75 per cent of threatened plant species in ex situ collections, preferably in the country of origin, and at least 20 per cent available for recovery and restoration programmes Botanic gardens are the main institutions involved in the ex situ conservation of wild plant diversity and many have adopted Target 8 as a target, either at an individual institutional level or as a national network target.

The number of botanic gardens in existence around the world has more than doubled in recent years and their combined plant collections, as recorded in BGCI's PlantSearch database $(<\mathrm{http} / /$ www.bgci.org/plant_search.php >), consist of at least 105,000 species equating to $30 \%$ of all known plants. A recent study revealed that botanic garden collections include some $41 \%$ of known threatened plant species but they are disproportionately temperate, with $93 \%$ of species held in the Northern Hemisphere. Consequently, an estimated $76 \%$ of species absent from living collections are tropical in origin. Furthermore, phylogenetic bias ensures that over $50 \%$ of vascular genera, but barely $5 \%$ of non-vascular genera, are conserved ex situ. Moreover, the study showed that while botanic gardens are discernibly responding to the threat of species extinction, just $10 \%$ of the global network capacity is devoted to threatened species. Of the $1,330,829$ records in PlantSearch, 134,771 or about $10 \%$ are threatened species, with $90 \%$ of ex situ collections devoted to species not yet identified to be at risk of extinction. If the network can hold over $41 \%$ of threatened species, with just $10 \%$ of current network capacity, there is potential to hold a greater proportion of threatened species (Mounce et al. 2017). 
Multiple accessions of threatened species across the network will buffer against loss of threatened species, and provide genetic diversity for ecological restoration efforts. However, $11 \%$ of globally threatened species are currently held in just one institution. Furthermore, over half of endemic threatened species are not held ex situ within their country of origin, implying reduced availability for ecological or species restoration.

With respect to Target 8 , only gymnosperms meet the target threshold, with $89 \%$ of threatened species held ex situ. As noted by Mounce et al., gymnosperms are a successful ex situ conservation story as: they are the least speciose of the major plant lineages, rendering the percentage-based GSPC Target 8 more feasible; there is a specific international conifer conservation programme; like most botanic gardens, they are broadly temperate; and they have horticultural value as evergreen collections. In stark contrast, the bryophytes, which have the poorest overall assessment rate of $12.2 \%$, are similarly impoverished with respect to ex situ conservation, such that only $2.6 \%$ of threatened bryophytes are documented in the botanic garden network.

Oceanic islands harbour disproportionally large numbers of endemic species, many of which are under significant threat of extinction. In a survey carried out in 2010, it was estimated that between 3,500 and 6,800 of the estimated 70,000 insular endemic plant species worldwide might be highly threatened $(\mathrm{CR}+\mathrm{EN})$ and between 2,000 and 2,800 of them in critical danger of extinction (CR) (Caujapé-Castells et al. 2010). While there has been no systematic survey to assess how many of these threatened species are conserved in ex situ conservation programmes, increasing efforts to conserve and seed-bank such species are on-going in a number of island communities, including Hawaii, Mauritius, and the Azores ( $<$ http://www. bgci.org/plant-conservation/seedbanking/>). While the focus of conservation work by botanic gardens in the past has been through their living collections, there is increasing recognition that such collections do not include sufficient intra-specific genetic diversity. A growing number of botanic gardens are now establishing seed banks - with the Millennium Seed Bank of the RBG, Kew, playing a key role in this respect. Over 370 botanical institutions in 74 countries around the world now collect and bank seed of wild species (O'Donnell and Sharrock, 2017) and BGCI has established the Global Seed Conservation Challenge to promote and support seed banks in botanic gardens. $(<\mathrm{http}: / /$ www.bgci. org/plant-conservation/seedconservation/ $>$ ).
Box 8 - The Australian Seed Bank Partnership

The 14 partners in the Australian Seed Bank Partnership have secured a third of Australia's flora in conservation seed banks with duplicate collections at the Millennium Seed Bank, including more than 34\% of the nation's threatened plants. The ASBP's 1,000 Species Project (2011-2020), a national collaboration, involves coordinating targeted seed collection of endangered, endemic or economically significant species not already represented in conservation seed banks, as well as working to enhance the provenance of existing collections. In collaboration with the Atlas of Living Australia, the Australian Seed Bank Online has been developed. This publically accessible database contains detailed records for over 43,100 seed collections. $<$ http://asbp.ala.org.au/>.

Target 9: 70 per cent of the genetic diversity of crops including their wild relatives and other socio-economically valuable plant species conserved, while respecting, preserving and maintaining associated indigenous and local knowledge

The diversity of local crops and their wild relatives plays a significant role in the livelihoods of many smallholder farming communities in developing countries.

At the global level, the Global Crop Diversity Trust (CDT) has been established to ensure the conservation of crop diversity for food security worldwide. It works within the framework of the International Treaty on Plant Genetic Resources for Food and Agriculture, which is the key global instrument for the conservation of genetic diversity for food and agriculture. The Svarlbard Global Seed Vault managed by the Crop Trust holds over 800,000 samples of crop diversity from more than 60 institutions around the world.

The Millennium Seed Bank in collaboration with the Global Crop Diversity Trust is engaged in a project called 'Adapting agriculture to climate change'. The main objective of this project is to collect, protect and prepare the wild relatives of the world's most important food crops in a form that plant breeders can readily use to produce varieties adapted to future climatic conditions that farmers in the developing world will soon be encountering. The project focuses on the wild relatives of 29 crops which are of major importance to food security, covered by Annex 
1 of the International Treaty of Plant Genetic

Resources for Food and Agriculture.

The major challenge with Target 9 is to identify and conserve the many thousands of other species that are of socio-economic importance at the national or local level as well as managing the indigenous knowledge associated with these species.

Box 9 - Conserving medicinal plants in Morocco

The Global Diversity Foundation (GDF) has been working with local partners to enhance local livelihoods in the Moroccan High Atlas while addressing threats to plant diversity. Drawing on indigenous knowledge and practice, the project goal was to ensure that Moroccan medicinal plants are conserved, sustainably harvested and profitably cultivated, thus improving the livelihoods of thousands of collectors, vendors and traditional practitioners. In situ and ex situ conservation activities helped ensure sustainable populations of vulnerable medicinal species while also sustaining plant-dependent livelihoods. A key outcome of the project was the establishment of thriving community plant nurseries. These act not only as ex situ conservation zones for medicinal and aromatic plants but also provide community members with income through the distribution of fruit and nut trees and useful plants, generating opportunities to transmit local knowledge and horticultural techniques while learning about innovative approaches such as drip irrigation.

$<$ https://www.global-diversity.org/mediterranean/medicinal-root-trade-plants-conservation-and-livelihoods-inmorocco/>.

In 2015, in relation to the conservation of Crop Wild Relatives (CWRs) and as part of their shared mandates, the CBD Secretariat together with the FAO Commission on Genetic Resources for Food and Agriculture (CGRFA), the International Treaty of Plant Genetic Resources for Food and Agriculture (ITPGRFA) and Bioversity International issued a notification identifying a number of actions to strengthen the inclusion of CWRs in protected area networks and other effective area-based conservation measures. $<$ https://www.cbd.int/ doc/notifications/2015/ntf-2015-092-gspc-en. pdf $>$.

Also relevant to the implementation of this Target are the Guidelines for Developing a National Strategy for Plant Genetic Resources for Food and Agriculture: translating the Second Global Plan of Action for Plant Genetic Resources for Food and Agriculture into National Action, as adopted by the Commission at its last session (<http://www.fao.org/3/amm566e.pdf $>$ ) as well as the Technical Guidelines on National Level Conservation and Use of Landraces and on National Level Conservation of Crop Wild Relatives, which are currently under preparation - see $<\mathrm{http}$ :// www.fao.org/3/a-mm564e.pdf $>$; and $<$ http:// www.fao.org/3/a-mm542e.pdf $>$.
Target 10: Effective management plans in place to prevent new biological invasions and to manage important areas for plant diversity that are invaded

Alien species that become invasive are considered to be a main direct driver of biodiversity loss across the globe. Alien species have been estimated to cost our economies hundreds of billions of dollars each year. The removal of invasive alien species is a key management activity for effective conservation. However experience has shown that preventing new invasions of harmful species is more cost-effective than waiting until they have become a threat. However, increasing global trade and the multiple pathways of introduction represent a major challenge to preventing new invasions. Applying preventative measures requires action at both international and national levels including the coordination of agencies working in the areas of plant health, transport, trade, tourism, protected areas, wildlife management and water supply.

While this target is best addressed at the national level, a new global initiative to develop an early warning for the new and emerging tree pests is the International Plant Sentinel Network (IPSN). The IPSN has been established to facilitate collaboration between botanic gardens and arboreta, National Plant Protection Organizations (NPPOs) and plant health scientists. The monitoring and 
surveying of exotic plant species in collections can provide an early warning of potential plant health risks to these species should the pests and diseases being monitored be introduced to the species' native environments.

Other significant initiatives include the Honolulu Challenge, launched at the 2016 IUCN World Conservation Congress in response to a call for more action on invasive alien species. It challenges countries and organizations to commit to taking bold yet practical measures necessary to safeguard biodiversity and human well-being from the devastating impacts of invasive alien species and has gathered commitments from governments and organizations to meet the aim of the Honolulu Challenge. In its Decision XIII/13 Parties to the CBD welcomed the Honolulu Challenge on Invasive Alien Species (CBD 2016f).

Box 10 - Managing invasive species in the UK

There are 1,402 non-native plants established in the wild in Great Britain, of which 108 (8\%) are stated to have a negative impact. Every year, approximately $£ 1.7$ billion is spent on trying to tackle the problem of invasive non-native species. The actual cost may be far greater as the 'indirect costs', such as damage to ecosystem service provision, are not accounted for. And then there's the damage to wildlife and waterways: millions of pounds are spent clearing invasive species from congested ponds and rivers with delicate rare water flowers such as starfruit (Damasonium alisma) pushed to extinction. $30 \%$ of the UK's Important Plant Areas have been found to have invasive species in them. In 2014, five non-native, invasive aquatic plants were banned from sale and in 2016, fourteen non-native, invasive plants were banned by the European Union. Of the 14 plant species, eight are plants that have proved popular with gardeners in the past. The GB Invasive Non-native Species Strategy, originally published in 2008 and updated in 2015, is intended to provide a strategic framework within which the actions of government departments, their related bodies and key stakeholders can be better co-ordinated.

$<$ www.gov.uk/government/uploads/system/uploads/attachment_data/file/455526/gb-non-native-species-strategypb14324.pdf $>$.

The "Global Islands Invasive Vertebrate Eradication Database" (see DIISE 2015 and Keitt et al. 2011) gives comprehensive information on the increasing number of eradications of vertebrate alien invasive species (mostly mammals), now reaching over 850 islands. However, we lack a comprehensive review of the outcomes and benefits of the eradication of mammal alien invasive species on the recovery of endemic or threatened plant species and associated vegetation. Schweizer et al. (2016) do provide a literature review and meta-analysis of vegetation responses to goat and European rabbit eradications on islands, finding that plant richness and vegetation cover increased more often than they decreased after eradication. Results varied according to region, herbivore type, habitat, and vegetation type, suggesting island-specific circumstances influence responses. The effect of eradication on Sub-Antarctic tundra species richness and on tropical vegetation percentage cover was higher than for other types of vegetation.
Target 11: No species of wild flora endangered by international trade

This target is unique in the context of the GSPC in that its implementation, monitoring and review is through linkages with the Convention on International Trade in Endangered Species of Wild Fauna and Flora (CITES) under its Plants Committee. This target is clearly consistent with the CITES Strategic Vision 2008-2020 (CITES Res. Conf. 16.3) which states to "Conserve biodiversity and contribute to its sustainable use by ensuring that no species of wild fauna or flora becomes or remains subject to unsustainable exploitation through international trade, thereby contributing to the significant reduction of the rate of biodiversity loss and making a significant contribution towards achieving the relevant Aichi Biodiversity Targets".

In 2013, at the $16^{\text {th }}$ meeting of the Conference of the Parties to CITES, a resolution on cooperation with the GSPC (Res. Conf. 16.5) was adopted. Amongst other things, Res. Conf. 16.5 invites Parties to promote and enhance collaboration between their GSPC focal point and their CITES Authorities. 
It is clear that CITES and the GSPC can share tools, scientific results and methodologies that relate mainly to Target 11 , but also have relevance to other targets such as taxonomy (Target 1) conservation assessments (Target 2) and capacity building (Target 15 ). Intensified communication between national CITES and GSPC authorities is an essential cornerstone for implementing joint collaborations of mutual benefit.

The unsustainable exploitation of plants for international trade is a continuing threat to the survival of many wild species. For example, the Global Assessment of Cacti, published in 2015 by the IUCN SSC Cactus and Succulent Specialist Group, found that $31 \%$ of cactus species are threatened with extinction. Cacti are under increasing pressure from human activity, with more than half of the world's 1,480 species being used by people. The illegal trade of live plants and seeds for the horticultural industry and private collections, as well as their unsustainable harvesting are the main threats to cacti, affecting $47 \%$ of threatened species ( $<$ http:// www.iucnredlist.org/news/cacti-assessment $>$ ).

Similarly, the international trade in timber is worth hundreds of billions of dollars every year and the increasing demand for luxury timber items is threatening the survival of many timber species. In recognition of this, at the last Conference of the Parties to CITES (COP17), all Dalbergia rosewood and palisander species found across the world, have been brought under CITES trade controls. In all, more than 300 tree species were added to CITES Appendix II in 2017. Particular concerns for CITES with respect to plants include controlling trade in tree species and their multiple derivatives (ranging from precious timber, logs and sawn wood to guitars and other musical instruments), the suspected undocumented trade in orchids, and trade in the highly valuable African cherry, East African sandalwood and agarwood. Almost 30,000 plant species are now protected under CITES, especially in its Appendix II.

Box 11 - Conservation and Cultivation of Galanthus woronowii in Georgia

The RBG, Kew, in its role as UK CITES Scientific Authority for Plants worked with the CITES Authorities in Georgia and Microsoft Research to ensure sustainable harvest of snowdrop (Galanthus woronowii) bulbs for the international horticultural trade. Georgia exports some 15 million wild bulbs per year and is now beginning to export propagated bulbs. The partners have carried out field surveys to assess the status of wild populations, modelled off-take/harvest, and recommended quotas and managements systems to meet CITES requirements. In addition, a checklist was developed for local application of the CITES definition of Artificial Propagation and a registration system for propagation fields was established and embedded in government regulations. Workshops, with the help of the UK Border Agency, were carried out to train local enforcement officials. Field surveys continue to expand the population data and research, when funding is obtained, efforts will be made to determine appropriate marking techniques to track the propagated bulbs entering international trade from Georgia.

Target 12: All wild harvested plantbased products sourced sustainably

The increasing demand for wild plants - as ingredients for food, cosmetics, well-being and medicinal products - poses major ecological and social challenges. The pressure on potentially vulnerable plant species can endanger local ecosystems and the livelihoods of collectors.

As a response to these concerns, the FairWild Foundation is working with partners worldwide to improve the conservation, management and sustainable use of wild plants in trade, as well as the livelihoods of rural harvesters involved in wild collection. TRAFFIC has supported the development of the FairWild Standard, and now provides the organisation's Secretariat under the basis of a partnership agreement. The FairWild Standard is now available in 17 different languages. Under the FairWild certification scheme, operational since 2010, 21 species have been certified in ten source countries (Bosnia and Herzegovina, Bulgaria, Georgia, Hungary, India, Kazakhstan, Poland, Serbia, Spain and Zimbabwe) and over 20 products are now sold in the USA, the European Union, Japan and other counties, labelled as 'FairWild' (<http://www.fairwild.org/>).

The Union for Ethical Biotrade (UEBT) has been tracking people's awareness of biodiversity and interest in ethical sourcing since 2009. Over the years, the UEBT Biodiversity Barometers have 
shows a close connection between people and biodiversity: high biodiversity in a country goes hand in hand with high biodiversity awareness and ability to describe it. Furthermore, High awareness of biodiversity translates in high expectations towards companies that use biodiversity. In the 2016 survey, $95 \%$ of respondents in Latin America (Brazil, Colombia, Ecuador, Mexico, Peru and Venezuela) said they expected companies to respect biodiversity, and 93\% say they would be more interested in buying from a company that pays attention to biodiversity. In the 2017 survey, UEBT showed that active contribution to biodiversity conservation (protection of local plants, such as wild flowers, or animals like bees) convinces people most that a brand respects people and biodiversity.

The 2017 review also highlighted that business is increasingly realising the importance of biodiversity as a vital source of innovation and inspiration. With the mounting importance of naturals, respect for biodiversity is imperative to assure long-term access to natural ingredients. There is also a growing realisation that biodiversity contributes to ecological resilience of sourcing areas, a key concern in time of climate change, and offers access to a gene pool that assures healthy populations or resistance to new pests $(<\mathrm{http}: / /$ www.biodiversitybarometer.org/\#biodiversitybarometer-reports-homepage $>$ ).

Box 12 - Sustainable wild harvesting of plants in the Danube region

The "Local Economy and Nature Conservation in the Danube Region" (LENA) project helps to promote the implementation of local sustainable wild plant harvesting activities. The project involves 13 partners from seven countries along the Danube. It aims to connect people to nature and support livelihoods and business opportunities for low-income communities based in and around protected areas. Four capacity-building workshops have been jointly organized with local project partners. Relevant stakeholders participated in the events, including representatives from local collectors, processing and trading companies, university experts, protected area authorities and local politicians actively participated in the events. Discussions focused on issues such as the threat of losing valuable traditional knowledge, the vanishing number of collectors, necessary training on sustainable harvesting practices, business planning and relevant legislation. The FairWild Standard and its Principles were introduced to the participants to demonstrate possible opportunities, solutions and best practice examples of successful sustainability frameworks to guide wild harvest and trade, including through the FairWild certification scheme.

$<$ http://www.traffic.org/home/2017/10/11/building-capacity-for-sustainable-wild-harvesting-of-wild-pl.html $>$.

Target 13: Indigenous and local knowledge innovations and practices associated with plant resources maintained or increased, as appropriate, to support customary use, sustainable livelihoods, local food security and health care

The preservation, protection and promotion of the traditional knowledge, innovations and practices of local and indigenous communities is of key importance, particularly for developing counties. Their rich endowment of traditional knowledge and biodiversity plays a critical role in their health care, food security, culture, religion, identity, environment, sustainable development and trade.

There is today a growing appreciation of the value of traditional knowledge. This knowledge is valuable not only to those who depend on it in their daily lives, but to modern industry and agriculture as well. Many widely used products, such as plant-based medicines and cosmetics, are derived from traditional knowledge. Other valuable products based on traditional knowledge include agricultural and non-wood forest products as well as handicrafts.

Although a wide range of initiatives to conserve traditional knowledge have been developed at national and local levels, progress towards this target is difficult to measure as baselines have not been quantified. In many ways, this is an 'enabling' target, supporting the achievement of other targets.

In May 2013, the Missouri Botanical Garden hosted an international workshop on the need for a global program on the conservation of useful plants and traditional knowledge. The workshop was attended by a number of international experts who issued a call to action which urged the development of a global programme on the conservation of useful 
plants and associated knowledge to address the loss of essential knowledge about plants and their uses, especially at the level of local communities. The participants concluded that there was a great urgency to address the vital importance of traditional knowledge about plants, their utility, management, and conservation. This unique, often ancient, and detailed knowledge is typically held and maintained by local and indigenous communities.

Through the adoption of the "Mo'otz Kuxtal Voluntary Guidelines on Traditional Knowledge", in CBD COP decision XIII/18 (CBD 2016d), governments are provided with practical guidance for the development of mechanisms, legislation, administrative and policy measures or other appropriate initiatives to ensure that potential users of knowledge, innovations and practices that are held by indigenous peoples and local communities, obtain the "prior and informed consent", "free, prior and informed consent" or "approval and involvement", and that indigenous peoples and local communities obtain a fair and equitable share of benefits arising from the use and application of such traditional knowledge and for reporting and preventing unlawful appropriation of traditional knowledge relevant for the conservation and sustainable use of biological diversity. The guidelines promote legal certainty and transparency concerning the use of traditional knowledge, including knowledge relevant to plant conservation, thereby facilitating the use of such knowledge.

Additionally, for the recovery of traditional knowledge associated with biodiversity, including plants, the Conference of the Parties of the CBD in its decision XIII/19 advanced work on the draft Rutzolijirisaxik Voluntary Guidelines for the Repatriation of Traditional Knowledge of Indigenous Peoples and Local Communities Relevant for the Conservation and Sustainable Use of Biological Diversity (CBD 2016e). The objective of these guidelines is to facilitate the repatriation of traditional knowledge of indigenous peoples and local communities in order to restore traditional knowledge for the objectives of the Convention. The guidelines are intended to provide practical guidance to Parties, Governments, international and regional organizations, museums, universities, herbaria and botanical and zoological gardens, databases, registers, gene banks, libraries, archives and information services, private collections and other entities storing or housing traditional knowledge and related information, and indigenous peoples and local communities, in efforts to repatriate traditional knowledge and related information.

Both the Mo'otz Kuxtal Voluntary Guidelines on Traditional Knowledge and the draft Rutzolijirisaxik Voluntary Guidelines for the Repatriation of Traditional Knowledge are supportive of Target 13.

Box 13 - Repatriation of local and indigenous knowledge

Repatriation of local and indigenous knowledge is a major research focus of the Missouri Botanical Garden's William L. Brown Center for Economic Botany in Bolivia, Peru and Madagascar. Over the past few years, traditional knowledge has been inventoried in joint research with indigenous counterparts in those countries. Results from communities in Peru (Awajun, Lamas, Arazaeri, Zapitaeri, Urarina, Cocama, Ese Eja), Bolivia (Chacobo, Lecos, Yuracare) and Madagascar have been published in local language books, as requested by communities. Previous studies translated from foreign languages (English, German) into Spanish and French have been repatriated in book form and online. Authorship of this traditional knowledge remains with the local communities.

$<$ http://www.missouribotanicalgarden.org/plant-science/plant-science/william-l-brown-center.aspx $>$.

Target 14: The importance

of plant diversity and the need

for its conservation incorporated

into communication, education

and public awareness programmes

Plants are often under-represented in the conservation debate and neglected in efforts to engage the public in environmental action. Furthermore, increasing urbanization and population movements are resulting in a growing disconnect between people and nature, a trend that is especially notable amongst the young. Plant conservation targets will only be achieved if changes are made at all levels of society, from policy makers through to the general public. For this reason, communication, education and public awareness programmes are essential in underpinning the GSPC. 
Although initiatives by the global botanic gardens community and others e.g., Fascination of Plants Day (see below) are reaching large numbers of people, there is still little evidence that this is having any policy impact. It is perhaps the failure of the achievement of this target that has led to continued difficulties in raising the profile and generating political support for urgent plant conservation action globally (Sharrock \& Wyse Jackson 2017).

Having said that, Fascination of Plants Day (May 18) continues to grow in popularity with over 830 events held in 52 countries around the world in 2017. Events were attended by a diverse range of people from all backgrounds and ages, and held at a variety of organizations including museums, universities, research institutes, schools and botanic gardens. The goal of the Fascination of Plants Day is to get as many people as possible around the world fascinated by plants and enthused about the importance of plant science for agriculture, in sustainably producing food, as well as for horticulture, forestry, and all of the non-food products such as paper, timber, chemicals, energy, and pharmaceuticals. The role of plants in environmental conservation is also a key message (<http://www.epsoweb.org/fascination-plants-day $>$ ).

Furthermore, in recent years there has been a spectacular growth of new botanic gardens that have a strong focus on public education. A striking example is provided by the Gardens by the Bay in Singapore which won the building for the year award in 2012 and attracts over 2.5 million visitors every year, representing an impressive commitment by the government of Singapore towards raising awareness about plants.

Engaging the public in new and innovative ways is key to raising awareness of plant conservation issues. One example is the increasing popularity of citizen-science projects focused around plant monitoring. Examples of such programmes include Project BudBurst in the USA $(<\mathrm{http}: / /$ budburst.org/>), Vigie-Nature in France $(<\mathrm{http}: / /$ www.naturefrance.fr/sciences-participatives/vigienature $>$ ) and the Phenology Recording System of the New Zealand Plant Conservation Network $(<\mathrm{http}: / /$ www.nzpen.org.nz/>).

Box 14 - Growing Beyond Earth

The Growing Beyond Earth project is part of The Fairchild Challenge, an award-winning environmental science competition based in Miami, USA and led by the Fairchild Tropical Botanic Garden. In 2016, the project, which administers plant experiments for middle and high school students, was awarded \$1.2 million by the National Aeronautics and Space Administration (NASA) to buy equipment for all participating schools. The students will test factors that might influence plant growth, flavor and nutrition in conditions mimicking the conditions aboard the International Space Station. NASA plans to use the students' results to identify edible plants that might be suitable for growth in space. The project helps to expand ongoing NASA research into a citizen science program for students, which includes experimental design, data collection and analysis, and a special emphasis on scientific communication.

$<$ https://www.fairchildgarden.org/nasa-challenge >.

Target 15: The number of trained people working with appropriate facilities sufficient according to national needs, to achieve the targets of this Strategy The scope of the GSPC goes beyond traditional plant conservation activities to include sustainable use, as well as working with local and indigenous communities. The achievement of the 16 targets requires considerable capacity-building, particularly to address the need for conservation practitioners trained in a range of disciplines. Such capacity is also important to address current and future grand challenges and issues facing society, including climate change mitigation, food security, land management and habitat restoration.
Progress towards Target 15 is considered key for the successful implementation of the GSPC. However available information suggests that progress is not only insufficient to meet the target, but that capacity building opportunities are actually declining in some areas / countries. If this is the case, this will have a significant impact on the ability of Parties to meet their commitments on biodiversity conservation.

Recognising the widening gaps in capacity, organizations in the non-governmental sector (e.g., botanic gardens and other non-profit conservation organizations, as well as for-profit businesses and self-employed individuals) are stepping in, providing botanical training, expertise and infrastructure where it otherwise would not exist. 
Box 15 - Sud Expert Plantes Développment Durable (SEP2D)

The SEP2D project aims to promote scientific research on plant diversity in Francophone countries of the South. It provides support for capacity building and international cooperation, and particularly promotes research partnerships involving the private sector, civil society and policy makers. The project supports multi-stakeholder projects as well as providing opportunities for North-South and South-South technology transfer. The SEP2D program, implemented by the IRD, is supported by a multi-donor partnership composed of the French Development Agency (AFD), the French Global Environment Facility (FFEM), the Ministry of Foreign Affairs and of International Development, the Research Institute for Development (IRD) and the National Museum of Natural History (MNHN).

$<$ https://www.ird.fr/les-partenariats/programmes-multilateraux/sud-expert-plantes-developpement-durable-sep2d $>$.

Target 16: Institutions, networks and partnerships for plant conservation established or strengthened at national, regional and international levels to achieve the targets of this Strategy

Networks supporting plant conservation activities provide the means to share experiences, exchange data, encourage professional development and build the capacity of the plant conservation community.

At the global level, the establishment of the GPPC has made a good start at bringing together the plant conservation community, and now includes over 50 partners $(<\mathrm{http}: / /$ www.plants2020.net/ gppcpartners/>). However greater efforts are needed to engage other sectors, such as agriculture, industry, education, forestry, Indigenous and Local Communities etc. This indicates a significant challenge for science communicators.

At the national level, there is still a lack of cross-sectoral networks, with limited institutional integration and a lack of mainstreaming of plant conservation work. However, where national responses to the GSPC have been developed, this has helped provide a focus for networking amongst the stakeholders, as can be seen from the example provided by South Africa (<http:// biodiversityadvisor.sanbi.org/planning-andassessment/plant-conservation-strategy/>).

Box 16 - The Global Oak Conservation Partnership

The Global Oak Conservation Partnership was initiated in 2015 between BGCI, Fauna and Flora International (FFI) and The Morton Arboretum. The project's aim is to prevent extinctions and ensure healthy populations of oak species for the future. This is accomplished by identifying and prioritizing threatened oak species and integrating tailored in situ protection and management activities in coordination with genetically diverse ex situ collections of living trees. The Partnership supports oak conservation in three regional oak diversity hotspots: Mexico \& Central America, the United States, and China \& Southeast Asia.

$<\mathrm{http} / /$ globaltrees.org/projects/global-oak-conservation-partnership/>.

\section{Discussion}

The Global Strategy for Plant Conservation (GSPC) has been widely adopted, particularly by the botanic garden community, and while unlikely to achieve its ultimate goal of halting the loss of plant diversity by 2020 , has achieved many successes, not least in allowing and facilitating many individuals and organisations from the botanical community to engage with the $\mathrm{CBD}$ and to contribute to the achievement of its objectives, targets and priorities. In focusing efforts around a set of easily understood, common targets, significant progress has been made in a number of areas, including the likely achievement of a World Flora on-line by 2020 (Target 1) and accelerated progress in plant red listing (Target 2), issues that underpin and support the achievement of many other targets.

The GSPC has also played an important role in helping to broaden the base of plant conservation activities worldwide, including increasingly sophisticated and effective responses to the growing threats to plant diversity and natural habitats. This has allowed and encouraged the development of new programmes related to plant conservation in such areas as conservation biology, 
conservation genetics, ecological restoration, climate change and mitigation, species recovery, the conservation of traditional knowledge relating to plants and in other areas.

However, to be truly successful, the scientific contribution of key players, such as botanic gardens needs to be strengthened, as does government policy and commitment. Botanic garden research to underpin conservation action, including the role of botanic garden horticulture, training and international capacity building, has a major part to play and needs to be better understood and better coordinated. Government policy, at national and international levels, needs to reflect the fundamental importance of plant diversity in maintaining the biosphere and supporting humanity (Blackmore et al. 2011; Smith 2016).

Government commitment to achieving plant conservation goals through the development of national plant conservation strategies has been demonstrated by relatively few countries. However, the development of such strategies has been shown to provide an important mechanism to bring together the wide range of stakeholders involved in plant conservation at the national level. In the case of South Africa for example, the strategy was developed under the leadership of SANBI, the focal point for the implementation of the GSPC nationally with support from the Botanical Society of South Africa (BotSoc). Through the development of this strategy a network of botanists was developed that includes conservation agencies, non-governmental organisations (NGOs) and academic institutions. It is this strong network that will ensure that South Africa's Strategy for Plant Conservation is implemented by 2020. South Africa's experience in ensuring the conservation of their extensive and unique plant diversity also provides some lessons for others. For example, in ensuring in situ conservation, the approach is not only to work on a species-by-species basis, but also to include a focus on comprehensively assessing which plants are priorities for conservation, mobilising the spatial data on where these taxa occur and feeding this information into the decision making processes for the country. This is primarily important in determining where protected areas are expanded and influencing the use of land to prevent transformation of remaining habitat occupied by plants of conservation concern.

The commitment of significant new resources is an essential prerequisite for success, but this needs to be well coordinated, inclusive of all stakeholders and carefully targeted. A further challenge is the need to integrate better the plant diversity-related activities of what are currently diverse and disconnected sectors, including agriculture, forestry, protected area management and botanic gardens (Blackmore et al. 2011). In this context, megadiverse countries face particular sets of challenges (e.g., Eline Martins et al. 2017).

It is clear that plant resources and wild habitats will require increasingly active management, including protection of remaining natural and semi-natural lands, as well as the restoration of natural capital, including ecological restoration and species recovery. Safeguarding the components of biodiversity, both in situ and ex situ will also play a part in ensuring not only that this biodiversity and associated ecosystem services remain available to support present-day and future use, but also that such biodiversity will be available for restoration and management purposes.

Redefining the objectives and targets of the GSPC beyond 2020 up to 2030 will be an essential part in continuing to engage the thousands of scientists, citizen scientists, ecologists, horticulturists, educators and activists around the world needed to achieve such targets. The Sustainable Development Agenda adopted by the UN General Assembly in 2015 can provide an important reference point for this work, helping to demonstrate the fundamental importance of plants for the planet, thereby contributing to the achievement of sustainable development, helping to alleviate poverty, providing new sustainable livelihoods and contributing to human wellbeing (Sharrock \& Wyse Jackson 2017).

\section{References}

Athens JS (2009) Rattus exulans and the catastrophic disappearance of Hawaii's native lowland forest. Biological Invasions 11: 1489-1501.

Auld TD, Hutton I, Ooi M \& Denham AJ (2010) Disruption of recruitment in two endemic palms on Lord Howe Island by invasive rats. Biological Invasions 12: 3351-3361.

Bachman SP, Lughadha EMN \& Rivers MC (2018) Quantifying progress toward a conservation assessment for all plants. Conservation Biology 32: 1-9.

Bernal R, Gradstein SR \& Celis M (2015) Catálogo de plantas y líquenes de Colombia. Instituto de Ciencias Naturales, Universidad Nacional de Colombia, Bogotá. Available at $<$ http:// catalogoplantasdecolombia.unal.edu.co $>$. Access on 15 February 2018. 
Blackmore S, Gibby M \& Rae D (2011) Strengthening the scientific contribution of botanic gardens to the second phase of the Global Strategy for Plant Conservation. Botanical Journal of the Linnean Society 166: 267-281. DOI: <https://doi.org/10.1111 /j.1095-8339.2011.01156.x>

Caujapé-Castells J, Tye A, Crawford DJ, Santos-Guerra A, Sakai A, Beaver K, Lobin W, Florens FBV, Moura M, Jardim R, Gómes I \& Kueffer C (2010) Conservation of oceanic island floras: present and future global challenges. Perspectives in Plant Ecology Evoloution and Systematics 12: 107-129. DOI: <https://doi. org/10.1016/j.ppees.2009.10.001>.

CBD (2016a) Progress in implementation of the targets of the Global Strategy for Plant Conservation 20112020. UNEP/CBD/SBI/1/INF/32, 23 March 2016. Available at $<$ https://www.cbd.int/doc/meetings/sbi/ sbi-01/information/sbi-01-inf-32-en.doc $>$. Access on 15 February 2018.

CBD (2016b) The Cancun Declaration on mainstreaming the conservation and sustainable use of biodiversity for well-being. UNEP/CBD/COP/13/24, 6 December 2016. Available at $<$ https://www.cbd.int/doc/c/e322/ f80c/0ee4f9289399a0fdd9f55317/cop-13-24-en.doc > . Access on 15 February 2018.

CBD (2016c) Strategic actions to enhance the implementation of the Strategic Plan for Biodiversity 2011-2020 and the achievement of the Aichi Biodiversity Targets, including with respect to mainstreaming and the integration of biodiversity within and across sectors. CBD/COP/DEC/XIII/3, 16 December 2016. Available at $<$ https://www.cbd.int/doc/decisions/cop-13/cop-13dec-03-en.doc $>$. Access on 15 February 2018.

CBD (2016d) Article 8(j) and related provisions: Mo'otz Kuxtal voluntary guidelines on traditional knowledge. CBD/COP/DEC/XIII/18, 17 December 2016. Available at $<$ https:/www.cbd.int/doc/decisions/cop13/cop-13-dec-18-en.doc $>$. Access on 15 February 2018.

CBD (2016e) Article 8(j) and related articles: other matters related to the programme of work - Annex. CBD/ COP/DEC/XIII/19, 12 December 2016. Available at $<$ https://www.cbd.int/doc/decisions/cop-13/cop-13dec-19-en.doc $>$. Access on 15 February 2018.

CBD (2016f) Invasive alien species: addressing risks associated with trade, experiences in the use of biological control agents, and decision support tools. CBD/COP/DEC/XIII/13, 13 December 2016. Available at $<$ https://www.cbd.int/doc/decisions/cop13/cop-13-dec-13-en.doc $>$. Access on 15 February 2018.

Darbyshire I, Anderson S, Asatryan A, Byfield A, Cheek M, Clubbe C, Ghrabi Z, Harris T, Heatubun CD, Kalema J, Magassouba S, McCarthy B, Milliken W, Montmollin B, Lughadha EN, Onana JM, Saïdou D, Sârbu A, Shrestha K \& Radford EA (2017) Important plant areas: revised selection criteria for a global approach to plant conservation. Biodiversity and
Conservation 26: 1767-1800. DOI: <https://doi. org/10.1007/s10531-017-1336-6>.

Dawson W, Moser D, van Kleunen M, Kreft H, Pergl J, Pyšek P, Weigelt P, Winter M, Lenzner B, Blackburn TM, Dyer EE, Cassey P, Scrivens SL, Economo EP, Guénard B, Capinha C, Seebens H, García-Díaz P, Nentwig W, García-Berthou E, Casal C, Mandrak NE, Fuller P, Meyer C \& Essl F (2017) Global hotspots and correlates of alien species richness across taxonomic groups. Nature Ecology \& Evolution 1, article number 0186: 1-7. DOI: <https://doi.org/10.1038/s41559017-0186>.

Dias BFS \& Hoft R (2013) Desafios para a implementação da Estratégia Global para a Conservação de Plantas no Brasil/Challenges Facing Implementation of the Global Strategy for Plant Conservation in Brazil, pp. 26-38. In: Martinelli G \& Moraes MA (orgs.). Livro Vermelho da Flora do Brasil (tradução Anderson F \& Hieatt C). Andrea Jakobsson \& Instituto de Pesquisas Jardim Botanico do Rio de Janeiro, Rio de Janeiro. 1100 p.

DIISE (2015) The database of island invasive species eradications, developed by island conservation, coastal conservation action laboratory UCSC, IUCN SSC invasive species specialist group, University of Auckland and Landcare Research New Zealand. Available at $<$ http://diise.islandconservation.org $>$. Access on 15 February 2018.

Martins E, Loyola R \& Martinelli G (2017) Challenges and perspectives for achieving the global strategy for plant conservation targets in Brazil. Annals of the Missouri Botanical Garden 102: 347-356.

Gutiérrez JL (2017) Modification of habitat quality by nonnative species $I n$ : Vilà M \& Hulme PE (eds.) Impact of biological invasions on ecosystem services. (Invading Nature series, 12). Springer, Cham. Pp. 33-47.

Harper GA \& Bunbury N (2015) Invasive rats on tropical islands: their population biology and impacts on native species. Global Ecology and Conservation 3: 607-627.

Hunt TL \& Lipo CP (2012) Ecological catastrophe and collapse: the myth of "Ecocide" on Rapa Nui (Easter Island). Property \& Environment Research Center. The Social Science Research Network Electronic Paper Collection. Available at $<$ http://www.ssrn.com/ link/PERC-PUB.html>. Access on 15 February 2018.

IUCN (2016) A global standard for the identification of key biodiversity areas, version 1.0. IUCN, Gland. 46p.

IUCN (2017) The red list of threatened species. Available at $<$ http://www.iucnredlist.org $>$. Access on 9 november 2017.

Joppa LN, Visconti P, Jenkins CN \& Pimm SL (2013) Achieving the convention on biological diversity's goals for plant conservation. Science 341, Issue 6150: 1100-1103. DOI: 10.1126/science. 1241706

Keitt B, Campbell K, Saunders A, Clout M, Wang Y, Heinz R, Newton K \& Tershy B (2011) The global islands invasive vertebrate eradication database: a tool to improve and facilitate restoration of island ecosystems. 
In: Veitch CR, Clout MN \& Towns DR (eds.). Island invasives: eradication and management. IUCN, Gland. Pp. 74-77.

Lovett JC (2004) 2002 Global strategy for plant conservation. Journal of African Law 48: 268-270.

Miller C \& Ulate W (2017) World flora online project: an online flora of all known plants. Biodiversity Information Science and Standards 1: e20529. DOI: $<$ https://doi.org/10.3897/tdwgproceedings.1.20529>.

Mounce R, Smith P \& Brockington S (2017) Ex situ conservation of plant diversity in the world's botanic gardens. Nature Plants 3: 795-802. DOI: 10.1038/ s41477-017-0019-3

O'Donnell K \& Sharrock S (2017) The contribution of botanic gardens to ex situ conservation through seed banking. Plant Diversity 39: 373-378.

Pyšek P, Blackburn PTM, Berthou EG, Perglová I \& Rabitsch W (2017) Displacement and local extinction of native and endemic species. In: Vilà M \& Hulme PE (eds.). Impact of biological invasions on ecosystem services. Cham, Switzerland, Springer. Invading Nature series 12: 157-175.

RBG Kew (2016) The state of the world's plants report 2016. Royal Botanic Gardens, Kew. 84p.

Rivers M (2017) The global tree assessment - red listing the world's trees. BGjournal 14: 16-19.

SCBD (2009) The convention on biological diversity plant conservation report: a review of progress in implementing the global strategy of plant conservation
(GSPC). Secretariat of the Convention on Biological Diversity, Montreal. 48p.

Schweizer D, Jones HP \& Holmes ND (2016) Literature review and meta-analysis of vegetation responses to goat and european rabbit eradications on islands. Pacific Science 70: 55-71.

Sharrock S, Oldfield S \& Wilson O (2014) Plant Conservation Report 2014: a review of progress in implementing the Global Strategy for Plant Conservation 2011-2020. Secretariat of the Convention on Biological Diversity, Montreal, Canada, and Botanic Gardens Conservation International, Richmond, U.K. Technical Series 81: 58p.

Sharrock S \& Jackson PW (2017) Plant conservation and the sustainable development goals: a policy paper prepared for the global partnership for plant conservation. Annals of the Missouri Botanical Garden 102: 290302. DOI: <https://doi.org/10.3417/D-16-00004A>.

Smith $\mathrm{P}$ (2016) Building a global system for the conservation of all plant diversity: a vision for botanic gardens and botanic gardens conservation international. Sibbaldia: 14: 5-13.

Stuart SN, Wilson EO, McNeely JA, Mittermeier RA \& Rodriguez JP (2010). The barometer of life. Science 328: 177.

The Plant List (2013) Version 1.1. Available at <http:// www.theplantlist.org/>. Access on 9 November 2017.

UNEP-WCMC \& IUCN (2016) Protected planet report (2016) UNEP-WCMC \& IUCN, Cambridge and Gland. VI+74p. 